\title{
PHOTOCATALYTIC DEGRADATION OF AZURE B UNDER VISIBLE LIGHT IRRADI- ATION BY REDUCED GRAPHENE OXIDE-NiS COMPOSITE
}

\author{
Ruchi Chaudhary ${ }^{1}$, Suresh C. Ameta ${ }^{1}$, Rakshit Ameta ${ }^{1,2^{*}}$ \\ ${ }^{1}$ Department of Chemistry, PAHER University, Udaipur-313003, India \\ ${ }^{2}$ Department of Chemistry, J. R. N. Rajasthan Vidyapeeth (Deemed to be University), \\ Udaipur-313001, India \\ rakshit_ameta@yahoo.in
}

\begin{abstract}
A composite of reduced graphene oxide (RGO) and nickel sulfide (NiS) was prepared via mechanochemical method and further characterized by X-ray diffraction (XRD), Fourier-transform infrared spectroscopy (FTIR) and energy dispersive analysis of X-rays (EDAX). NiS was prepared via precipitation method, and RGO was prepared via reduction of graphene oxide. The photocatalytic performances of as prepared $\mathrm{RGO} / \mathrm{NiS}$ composite, $\mathrm{RGO}$ and $\mathrm{NiS}$ were evaluated using azure B model system. The composite exhibited good photocatalytic activity as compared to NiS as well as RGO. The optimum conditions obtained for the photocatalytic degradation of azure $\mathrm{B}$ were the following: $\mathrm{pH}=8.0,[$ Azure $\mathrm{B}]=2.0 \times$ $10^{-5} \mathrm{M}$, amount of composite $=0.10 \mathrm{~g}$, and light intensity $=50.0 \mathrm{~mW} \cdot \mathrm{cm}^{-2}$. The rate of degradation of azure B with the composite was found to be $1.79 \times 10^{-4} \mathrm{~s}^{-1}$.
\end{abstract}

Keywords: reduced graphene oxide; nickel sulfide; azure B; photocatalytic degradation

\section{ФОТОКАТАЛИТИЧКО РАЗЛОЖУВАњЕ НА АЗУР В ПОД ДЕЈСТВО НА ВИДЛИВА СВЕТЛИНА СО КОМПОЗИТ ОД РЕДУЦИРАН ГРАФЕНОВ ОКСИД-NiS}

\begin{abstract}
Подготвен е композит на редуциран графенов оксид (RGO) и никелов сулфид (NiS) co механохемиски метод и потоа карактеризиран со рендгенска дифракција (XRD), Фуриеова трансформна инфрацрвена спектроскопија (FTIR) и анализа на дисперзија на енергијата (EDAX). $\mathrm{NiS}$ е приготвен со метод на таложење, додека RGO е приготвен со редукција на графенов оксид. Фотокаталитичката способност на приготвениот композит од RGO/NiS, како и на RGO и на NiS e одредена со употреба на моделниот систем на азур В. Композитот покажа добра фотокаталитичка активност како во однос на NiS така и на RGO. Оптимални услови за фотокаталитичката деградација на азур В ce: $\mathrm{pH}=8,0$, [азур В] $=2,0 \times 10^{-5} \mathrm{M}$, количина на композит $=0,10 \mathrm{~g}$ и интензитет на светлина $=50,0 \mathrm{~mW} \cdot \mathrm{cm}^{-2}$. Брзината на деградација на азур В со композитот изнесуваше $1,79 \times 10^{-4} \mathrm{~s}^{-1}$.
\end{abstract}

Клучни зборови: редуциран графенов оксид; никел сулфид; азур В; фотокаталитичка деградација

\section{INTRODUCTION}

Water pollution is currently a common problem. Water pollution involves the mixing of one or more substance that is harmful to humans and animals into water. Water pollution can be caused by many sources, but industrial waste water is a salient issue. Effluents from textile dyes present a substantial problem because they can cause many dangerous diseases and lead to death.
There are many available techniques for waste water treatment, such as precipitation, flocculation, adsorption, thermal dehydration, air stripping, etc.; however, photocatalysis plays an important role in water purification, and numerous studies are being conducted for this purpose. In the last few years, the use of graphene oxide and reduced graphene oxide for waste water treatment has attracted the attention of researchers. Apart from this use, composites of reduced grapheneox- 
ide have found applications as counter electrodes in dye-sensitized solar cells $[1,2]$, in reversible lithium storage [3], in hydrogen evolution reactions [4], as supercapacitors [5], etc.

Vadivel et al. [6] prepared a graphene oxide$\mathrm{BiOBr}$ composite material and used it as a highly efficient photocatalyst for the degradation of methylene blue and rhodamine-B dyes, and Wang et al. [7] prepared a graphene-oxide/ $\mathrm{Ag}_{3} \mathrm{PO}_{4}$ composite and used it for the photocatalytic degradation of bisphenol A under visible light irradiation. RGO is known to be well-suited for optical, biosensor, medical and supercapacitor applications, but RGO may also play an important role in photocatalysis. Wang et al. [8] used solvothermal method to synthesize reduced graphene oxide/cadmium sulfide (RGO/CdS). CdS nanoparticles were homogeneously distributed on reduced graphene oxide. This composite showed enhanced photocatalytic properties for methylene blue. Moreover, Chakraborty et al. [9] used a RGO/CdS composite to degrade 4nitrophenol under simulated solar light illumination. In this process, the reduction of graphene oxide (GO) and the attachment of CdS particles onto RGO sheets were performed simultaneously. These authors reported photoinduced electron transfers from CdS nanorods to RGO sheets, and this process reduced the recombination probability of photogenerated electron-holes in the CdS. Their study established that the RGO-CdS composite is a potential photocatalyst for degradation.

A facile microwave method has been used to synthesize a zinc oxide/reduced graphene oxide (ZnO-RGO) nanocomposite in the presence of diethylenetriamine [10]. $\mathrm{ZnO}$ nanorods were successfully deposited on RGO sheets. This composite showed excellent performance via enhanced adsorption-photocatalysis under the irradiation of sunlight. This photoactivity was due to the $\mathrm{ZnO}$ nanorods, and the RGO acted as a photosensitizer. Shen et al. [11] reported a one-pot ionic-liquidassisted hydrothermal process, in which $\mathrm{ZnCdS}$ nanoparticles were decorated on RGO. The synthesis of RGO and preparation of the $\mathrm{ZnCdS/RGO}$ composite were achieved simultaneously. The composite exhibited excellent photodegradation properties for organic dyes. Yan et al. [12] synthesized a $\mathrm{Cu}_{2} \mathrm{O} / \mathrm{PA} / \mathrm{RGO}$ composite and used it for photocatalytic dye degradation. $\mathrm{Cu}_{2} \mathrm{O}$ nanoparticles were successfully synthesized on $n$-propylamine intercalated graphene oxide, and hydrazine hydrate reduction was subsequently applied to synthesize the desired composite. This composite exhibited significant improvements in both photocatalytic activity and adsorption capacity.
Nickel sulfide nanoparticles have been synthesized in the presence of thioacetamide or thiourea to act as a sulfur source with variations in temperature and capping agents. Molla et al. [13] reported that this catalyst has the ability to generate reactive oxygen species in both the absence and presence of light. This property is responsible for dye decomposition. This catalyst was tested on crystal violet, rhodamine B, methylene blue, Nile blue and Eriochrome black T. Pouretedal and Momenzadeh [14] used a controlled precipitation method to synthesize $\mathrm{Ni}_{2} \mathrm{~S}_{3}, \mathrm{NiS}, \mathrm{NiO}, \mathrm{NiO}_{0.5} \mathrm{~S}_{0.5}$ and $\mathrm{Ni}_{2} \mathrm{O}_{1.5} \mathrm{~S}_{1.5}$. These catalysts were then calcined at $700^{\circ} \mathrm{C}$, and their photocatalytic dye degradation efficiencies were compared using a methylene blue model dye system. These authors observed the following trend:

$$
\mathrm{Ni}_{2} \mathrm{O}_{1.5} \mathrm{~S}_{1.5}>\mathrm{NiO}_{0.5} \mathrm{~S}_{0.5}>\mathrm{NiS}>\mathrm{NiO}>\mathrm{Ni}_{2} \mathrm{O}_{3}>\mathrm{Ni}_{2} \mathrm{~S}_{3}
$$

Rosu et al. [15] performed photocatalytic degradations of the azo dyes amaranth, sunset yellow and tartrazine using $\mathrm{TiO}_{2}-\mathrm{Pt}$ nanoparticles, $\mathrm{TiO}_{2}-\mathrm{Pt} /$ graphene oxide and $\mathrm{TiO}_{2}-\mathrm{Pt} /$ reduced graphene oxide composites in the presence of UV and natural sunlight irradiation, and Fan et al. [16] reported the use of zinc oxide $(\mathrm{ZnO}) /$ reduced graphene oxide $(\mathrm{rGO})$ hybrids for the degradation of methylene blue, methylene orange, and rhodamine 6G upon ultraviolet light irradiation. Ucar et al. [17] prepared a silicotungstic acid ( $\mathrm{SiW}$ )-decorated reduced graphene oxide (rGO) nanocomposite (rGO-SiW) and evaluated it as a heterogeneous nanocatalyst for the degradation reactions of methylene blue and rhodamine B. Mittal et al. [18] independently evaluated the photocatalytic degradation of azure B using manganese dioxide as a photocatalyst. While studying the rate-affecting parameters, these authors observed that the photocatalytic degradation of azure B followed firstorder kinetics. Ameta et al. [19] studied the effects of operating parameters on the photocatalytic degradation of azure $\mathrm{B}$ dye using calcium oxide as a photocatalyst. Upadhyay et al. [20] examined the photodegradation of azure B under visible irradiation in the presence of copper hexacyanoferrate(II) as a photocatalyst. After studying the rate-affecting parameters, these authors concluded that, after exposure to light and the photocatalyst for 2 hours, $86 \%$ of the azure B dye was degraded following the addition of $0.05 \mathrm{~g} / 50 \mathrm{ml}$ copper hexacyanoferrate (II) to a $1 \times 10^{-5} \mathrm{M}$ solution of azure B. Aarthi et al. [21] investigated the photocatalytic degradations of azure A, azure B and Sudan dyes (III and IV) by combustion-synthesized $\mathrm{TiO}_{2}$ and Degussa 
$\mathrm{P}-25$. The photodegradation rate was found to be higher in solvents with higher polarities, and metal ions reduced the photocatalysis rates. Keeping the hazardous effect of azure B dye in focus, in the present work, a RGO/NiS composite was produced and used in presence of light to degrade the dye. The RGO/NiS composite was found to be a good photocatalyst for degradation of azure B. Because this composite is insoluble in water, it is easy to remove from treated water.

\section{MATERIALS AND METHODS}

\subsection{Chemicals}

Graphite was purchased from Merck, and $\mathrm{NiSO}_{4}$ and ascorbic acid were purchased from Himedia.

\subsection{Preparation of $R G O, N i S$ and the composite}

The RGO was synthesized from graphite by a new green chemical route, and $\mathrm{NiS}$ was produced by a precipitation method. The RGO was synthesized from graphite in a process involving the oxi- dation of graphite in the first step followed by the reduction of the obtained graphene oxide into reduced graphene oxide. The oxidation of graphite was performed with singlet oxygen, and the reduction was achieved with ascorbic acid. Singlet oxygen and ascorbic acid are eco-friendly chemicals. The composite of RGO and NiS was prepared with a mechanochemical method following a top-down approach. Equal amounts of RGO and NiS were ground with an agate mortar pestle.

\subsection{Characterization}

\subsubsection{X-ray diffraction $(X R D)$}

The crystal size of the prepared RGO was determined with an X-ray diffractometer (XRD) (XPERT-PRO model, SAIF, Chandigarh) using $\mathrm{CuK} \alpha$ radiation $(\lambda=0.154060 \mathrm{~nm})$ in the $2 \theta$ scanning range from $20^{\circ}$ to $80^{\circ}$ with a scan rate at $10^{\circ}$ $\min ^{-1}$. The applied voltage and current were $45 \mathrm{kV}$ and $40 \mathrm{MA}$, respectively. The powder XRD pattern of a prepared RGO is shown in Figure 1.

RGO exhibits an intensity and broadness peak at $2 \theta=26.45^{\circ}$, and the average particle size is 26.75 $\mathrm{nm}$. The characteristic peak of the RGO is at $27.6^{\circ}$.

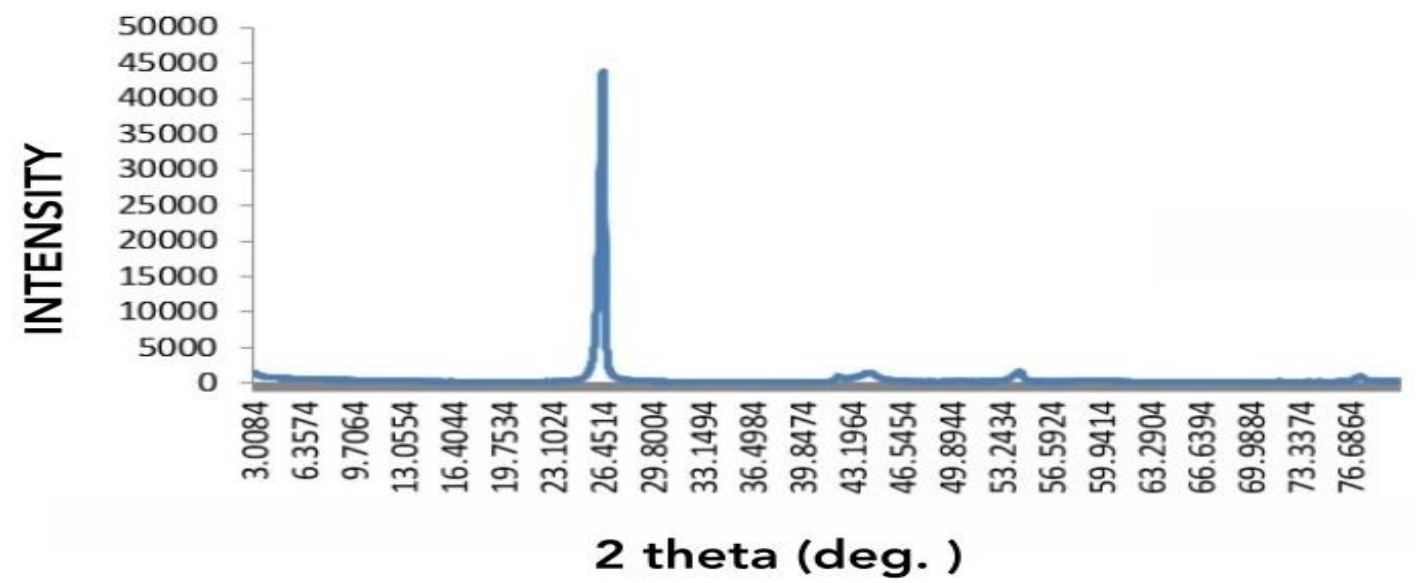

Fig. 1. XRD pattern of RGO

\subsubsection{Fourier-transform infrared spectroscopy (FTIR)}

The FTIR spectrum of the synthesized RGO-CuS composite was recorded with a Bruker spectrometer (SAIF, Chandigarh) in the range of 4000 to $400 \mathrm{~cm}^{-1}$ at a scanning rate of $1 \mathrm{~cm}^{-1} / \mathrm{min}$.

The FTIR studies were performed to confirm the presence of NiS in the composite. The
FTIR of the prepared RGO-NiS composite is shown in Figure 2. The characteristic peak of NiS$\mathrm{C}$ was obtained at $1576 \mathrm{~cm}^{-1}$, and the $\mathrm{Cu}-\mathrm{S}$ vibration peak was located at $942 \mathrm{~cm}^{-1}$. The presence of these two peaks indicated that the NiS had been incorporated into the RGO in the composite. The peaks at 1393 and $1622 \mathrm{~cm}^{-1}$ may be attributable to the $\mathrm{O}-\mathrm{H}$ deformations of the $\mathrm{C}-\mathrm{OH}$ and carboxy $\mathrm{OH}$ in the RGO [22-24]. 


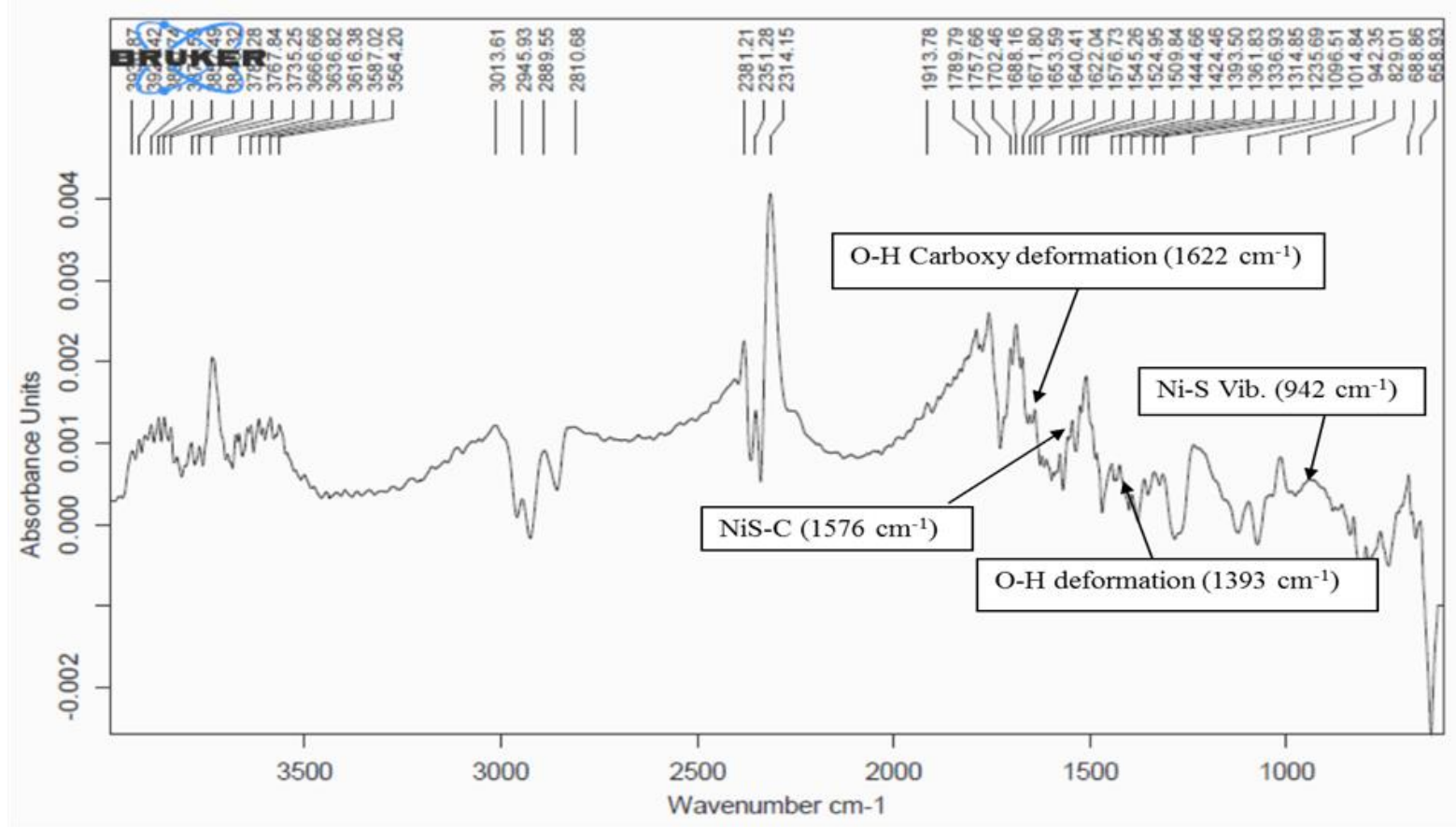

Fig. 2. FTIR pattern of the RGO-NiS composite

\subsubsection{Energy dispersive analysis of $X$-rays} (EDAX)

The elemental composition was determined with an energy dispersive X-ray (EDAX) spectrometer. The results are summarized in Table 1.

Table 1

EDAX results for $R G O$

\begin{tabular}{cc}
\hline \hline Element & Weight $\%$ \\
\hline Carbon & 99.41 \\
Oxygen & 0.59 \\
\hline \hline
\end{tabular}

\subsection{Photocatalytic degradation}

Azure B $(0.0305 \mathrm{~g})$ was dissolved in $100 \mathrm{ml}$ of doubly distilled water to achieve a concentration of dye solution of $1.0 \times 10^{-3} \mathrm{M}$. This solution was used as a stock solution and was further diluted when required. The absorbance of azure $\mathrm{B}$ was determined spectrophotometrically at $\lambda_{\max }=650 \mathrm{~nm}$.

Equal amounts of dye solution were placed in four beakers. The first beaker containing azure B solution was kept in the dark, and the second beaker containing azure B was exposed to light. The third beaker containing azure B solution and $0.10 \mathrm{~g}$ of the RGO/NiS composite was kept in the dark, and the fourth beaker containing azure B so- lution and $0.10 \mathrm{~g}$ of the $\mathrm{RGO} / \mathrm{NiS}$ composite was exposed to light. After 3-4 h, the absorbance of the solution in each beaker was measured with a spectrophotometer (Systronics Model 106). The absorbances of the solutions in the first three beakers remained almost the same. However, in the fourth beaker, the absorbance decreased relative to the initial value. Based on these observations, it was clear that this reaction was photocatalytic in nature because it required the presence of both; light and the RGO/NiS composite.

A solution of $2.0 \times 10^{-5} \mathrm{M}$ azure B was prepared in doubly distilled water, $0.1 \mathrm{~g}$ of $\mathrm{RGO} / \mathrm{NiS}$ composite was added, and the $\mathrm{pH}$ of this solution was adjusted to 8.0. Next, this reaction solution was exposed to a $200 \mathrm{~W}$ tungsten lamp at 50.0 $\mathrm{mW} \cdot \mathrm{cm}^{-2}$. A decrease in the absorbance of the dye solution with increasing time of exposure was observed.

\section{RESULTS AND DISCUSSION}

The plot of $1+\log$ A against time was found to be linear (Table 2 and Fig. 3). This graph indicates that the photocatalytic degradation of azure B followed pseudo-first order kinetics.

The rate constant $(k)$ was calculated using equation (1).

$$
k=2.303 \times \text { slope }
$$


Table 2

\begin{tabular}{|c|c|c|}
\hline Time (min.) & Absorbance (A) & $1+\log A$ \\
\hline 0.0 & 0.612 & 0.7866 \\
\hline 10.0 & 0.560 & 0.7481 \\
\hline 20.0 & 0.530 & 0.7242 \\
\hline 30.0 & 0.446 & 0.6493 \\
\hline 40.0 & 0.399 & 0.6009 \\
\hline 50.0 & 0.383 & 0.5831 \\
\hline 60.0 & 0.355 & 0.5502 \\
\hline 70.0 & 0.322 & 0.5078 \\
\hline 80.0 & 0.297 & 0.4727 \\
\hline 90.0 & 0.264 & 0.4216 \\
\hline 100.0 & 0.238 & 0.3766 \\
\hline 110.0 & 0.224 & 0.3502 \\
\hline 120.0 & 0.210 & 0.3222 \\
\hline 130.0 & 0.186 & 0.2695 \\
\hline 140.0 & 0.166 & 0.2201 \\
\hline 150.0 & 0.151 & 0.1789 \\
\hline
\end{tabular}

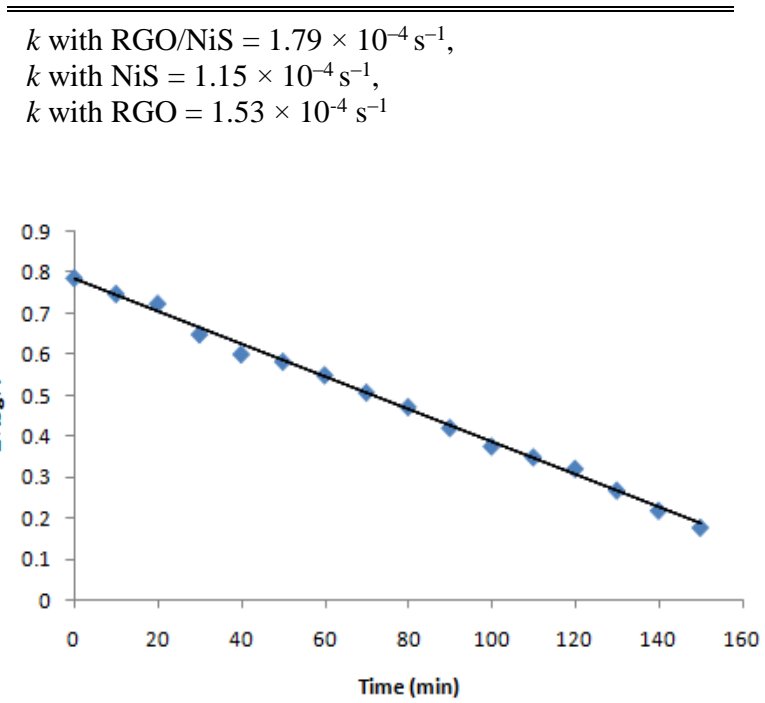

Fig. 3. A typical run

Different rate-affecting parameters, such as $\mathrm{pH}$, azure B concentration, amount of RGO/NiS composite and light intensity, were studied to obtain the optimum conditions for the photocatalytic degradation of azure B.

\subsection{Effect of $p H$}

The $\mathrm{pH}$ of the solution of azure B was varied across the range of 5.0-10.0. The results are shown in Table 3.

The rate of degradation was observed to increase with increasing $\mathrm{pH}$ until it reached a maximum at $\mathrm{pH}$ 8.0. At $\mathrm{pH}$ values below 8.0, a decrease in the rate of the reaction was observed due to the repulsion between the cationic dye molecules and the positively charged surface of the composite due to the adsorption of protons. When the $\mathrm{pH}$ was increased towards 8.0, the rate of the reaction was enhanced. This result may be explained by the fact that more $\mathrm{OH}^{-}$ions were available at higher $\mathrm{pH}$ values; consequently, more ${ }^{\circ} \mathrm{OH}$ radicals were produced, and thus, the reaction rate increased. At $\mathrm{pH}$ values above 8.0, the cationic dye molecules converted into the neutral form, which exhibited no attraction toward the negatively charged surface of the composite due to the adsorption of $\mathrm{OH}^{-}$ions; consequently, the rate was retarded.

T a ble 3

\section{Effect of $\mathrm{pH}$}

[azure B] $=2.00 \times 10^{-5} \mathrm{M}$, light intensity $=50.0$ $\mathrm{mW} \cdot \mathrm{cm}^{-2}$, amount of RGO/NiS composite $=0.10 \mathrm{~g}$

\begin{tabular}{cc}
\hline \hline $\mathrm{pH}$ & Rate constant $(\mathrm{k}) \times 10^{4}\left(\mathrm{~s}^{-1}\right)$ \\
\hline 5.0 & 1.11 \\
5.5 & 1.18 \\
6.0 & 1.25 \\
6.5 & 1.31 \\
7.0 & 1.36 \\
7.5 & 1.52 \\
8.0 & 1.79 \\
8.5 & 1.71 \\
9.0 & 1.43 \\
9.5 & 1.26 \\
10.0 & 1.13 \\
\hline \hline
\end{tabular}

\subsection{Effect of azure B concentration}

Different concentrations of azure B (1.40 $2.80 \times 10^{-5} \mathrm{M}$ ) were used to study the effect of the dye concentration on photocatalytic degradation. The results are presented in Table 4.

Table 4

Effect of dye concentration $p H=8.0$, light intensity $=50.0 \mathrm{~mW} \cdot \mathrm{cm}^{-2}$, amount of RGO/NiS composite $=0.10 \mathrm{~g}$

\begin{tabular}{cc}
\hline \hline [Azure B] $\times 10^{5} \mathrm{M}$ & Rate constant $(\mathrm{k}) \times 10^{4}\left(\mathrm{~s}^{-1}\right)$ \\
\hline 1.40 & 0.96 \\
1.60 & 1.09 \\
1.80 & 1.42 \\
2.00 & 1.79 \\
2.20 & 1.22 \\
2.40 & 1.15 \\
2.60 & 1.07 \\
2.80 & 0.92 \\
\hline \hline
\end{tabular}


These observations revealed that the rate constant increased with increasing dye concentration, but after exceeding the dye concentration of $2.00 \times 10^{-5} \mathrm{M}$, the rate decreased. The rate constant increased with the dye concentration because a greater number of dye molecules were available for excitation and energy transfer. The rate constant reached a maximum at a concentration of $2.00 \times 10^{-5} \mathrm{M}$, and it decreased with further increases in the concentration. After reaching a certain concentration, the dye molecules begin to act as a filter of incident light and do not allow the desired light intensity to reach the surface of the photocatalyst.

\subsection{Effect of the amount of RGO/NiS composite}

The amount of the composite may also affect the degradation of azure B. To observe the effect of the amount of the RGO/NiS composite, this amount was varied from 0.06 to $0.18 \mathrm{~g}$. The results are summarized in Table 5. Here, the rate of the photocatalytic degradation of azure B increased with increasing amounts of the composite. At a certain point, i.e., $0.10 \mathrm{~g}$, maximum degradation of the dye was achieved; thereafter, a decrease in the rate of photocatalytic degradation was observed with further increases in the amount of RGO/NiS composite.

\section{Table 5}

\begin{tabular}{|c|c|}
\hline Amount of composite (g) & Rate constant $(\mathrm{k}) \times 10^{4}\left(\mathrm{~s}^{-1}\right)$ \\
\hline 0.06 & 0.97 \\
\hline 0.07 & 1.12 \\
\hline 0.08 & 1.38 \\
\hline 0.10 & 1.79 \\
\hline 0.12 & 1.45 \\
\hline 0.14 & 1.34 \\
\hline 0.16 & 1.18 \\
\hline 0.18 & 0.99 \\
\hline
\end{tabular}

The rate of degradation of the azure $\mathrm{B}$ increased with increasing amounts of the composite, which may have been due to a corresponding increase in its exposed surface area. However, upon increasing the amount of composite above $0.10 \mathrm{~g}$, a decrease in the rate of degradation was observed. This result may have been due to the fact that there was no increase in the exposed surface area above a particular limit; however, in this case, the formation of a multilayer may have occurred and made electron-hole recombination easier. This recombination would act against the photocatalytic degradation of azure $\mathrm{B}$ because fewer ${ }^{\circ} \mathrm{OH}$ radicals would be formed, and $\mathrm{OH}$ radicals are the main reactive oxidizing species. This notion was confirmed by stirring the solution, which resulted in a shift of the optimum amount to a higher value.

\subsection{Effect of light intensity}

The effect of light intensity on the photocatalytic degradation of the dye was observed by changing the distance between the light source and the surface of the composite. The results are presented in Table 6.

T able 6

Effect of light intensity

[azure B] $=2.00 \times 10^{-5} \mathrm{M}, \mathrm{pH}=8.0$,

amount of RGO/NiS composite $=0.10 \mathrm{~g}$

\begin{tabular}{cc}
\hline \hline Light intensity $\left(\mathrm{mWcm}^{-2}\right)$ & Rate constant $(\mathrm{k}) \times 10^{4}\left(\mathrm{~s}^{-1}\right)$ \\
\hline 20.0 & 0.96 \\
30.0 & 1.45 \\
40.0 & 1.51 \\
50.0 & 1.79 \\
60.0 & 1.57 \\
70.0 & 1.45 \\
\hline \hline
\end{tabular}

Increasing light intensity was found to increase the rate of the degradation of the dye. The optimum degradation was obtained at 50.0 $\mathrm{mW} \cdot \mathrm{cm}^{-2}$. Thereafter, the rate decreased with further increases in light intensity. This increase in photocatalytic degradation may have resulted from an increase in the number of photons that struck per unit area per unit time and thus increased the light intensity. After this optimum value, a decrease in photocatalytic degradation was observed and may have been due to thermal side reactions; therefore, greater light intensities were avoided.

\subsection{Mechanism}

Based on these observations, a tentative mechanism for the photocatalytic degradation of azure $B(A B)$ is proposed as follows: 


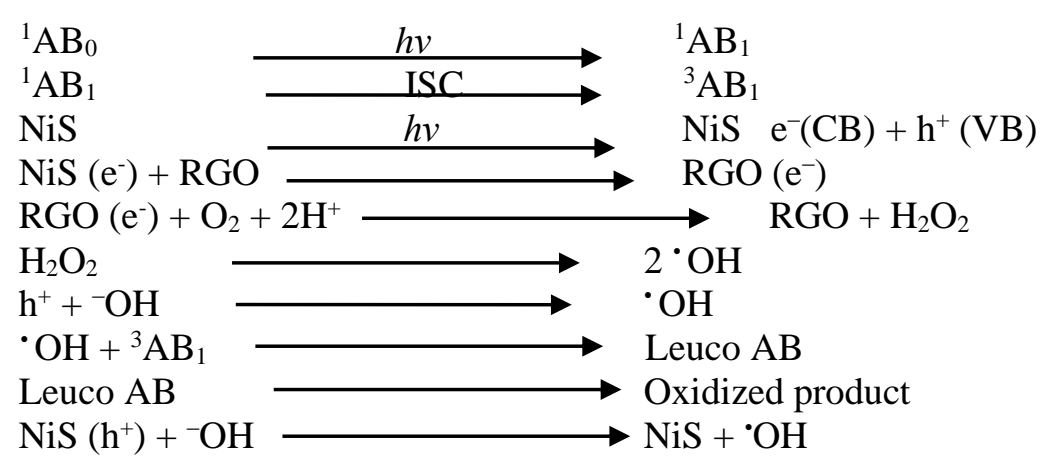

The molecules of azure B absorbed light of a suitable wavelength and were excited to the first excited singlet state, upon which they further underwent intersystem crossing to the triplet state. Semiconducting NiS also absorbs light, and the electrons were excited to their conduction band, which left a hole in their valence band. The electrons from the conduction band may have been abstracted by RGO, which acts as an electron sink. Similarly, the electrons were abstracted from the $\mathrm{OH}^{-}$ions by the hole in the valence band of the $\mathrm{NiS}$, which generated ${ }^{\circ} \mathrm{OH}$ radicals. ${ }^{\circ} \mathrm{OH}$ radicals are an active oxidizing species and oxidized azure B to its leuco form, which was ultimately degraded to smaller and almost harmless products. Isopropanol is a specific hydroxyl radical scavenger. Hence, isopropanol was added to reaction mixture, and the reaction rate was drastically reduced, which confirmed the active participation of the $\cdot \mathrm{OH}$ radicals as an active oxidizing species.

\section{CONCLUSION}

Photocatalysis is an emerging field and can be used to degrade various pollutants in an ecofriendly manner. In the present work, azure B dye was successfully degraded in the presence of an RGO/NiS composite and light. After the exposure of an azure B-containing sample to the composite and light for approximately $4 \mathrm{~h}, 90 \%$ of the dye content was found to be degraded. This observation revealed that the RGO/NiS composite exhibited better results than either RGO or NiS. Photocatalysis will prove to be an efficient method for the treatment of waste water that contains different organic contaminants in the future.

\section{REFERENCES}

[1] A. Sarkar, A. K. Chakraborty, S. Bera, NiS/rGO nanohybrid: An excellent counter electrode for dye sensitized solar cell, Solar Energy Materials and Solar Cells, 182, 314-320 (2018). DOI:10.1016/j.solmat.2018.03.026
[2] Z. Li, F. Gong, G. Zhou, Z.-S. Wang, NiS 2 /Reduced Graphene Oxide nanocomposites for efficient dyesensitized solar cells, The Journal of Physical Chemistry C, 117, 6561-6566 (2013). DOI:10.1021/jp401032c

[3] Y. Tan, M. Liang, P. Lou, Z. Cui, Z., X. Guo, W. Sun, X. $\mathrm{Yu}$, In situ fabrication of $\mathrm{CoS}$ and NiS nanomaterials anchored on reduced graphene oxide for reversible lithium storage, ACS Applied Materials \& Interfaces, 8, 1448814493 (2016). DOI:10.1021/acsami.6b01003

[4] L. Li, J. Wu, B. Liu, X. Liu, C. Li, Y. Gong, L. Pan, NiS sheets modified CdS/reduced graphene oxide composite for efficient visible light photocatalytic hydrogen evolution, Catalysis Today, 315, 110-116 (2018). DOI:10.1016/j.cattod.2018.03.072

[5] P. Rambabu, S. K. Srivastava, P. Das, G. R. Turpu, rGO$\mathrm{SnO} 2$ Composites for supercapacitor applications, IOP Conf. Series: Materials Science and Engineering, 149 (2016). DOI:10.1088/1757-899X/149/1/012169

[6] S. Vadivel, M. Vanitha, A. Muthukrishnaraj, N. Balasubramanian, Graphene oxide- $\mathrm{BiOBr}$ composite material as highly efficient photocatalyst for degradation of methylene blue and rhodamine-B dyes. J. Water Process Eng., 1, 17-26 (2014). DOI:10.1016/j.jwpe.2014.02.003

[7] C. Wang, J. Zhu, X. Wu, H. Xu, Y. Song, J. Yan, H. Li, Photocatalytic degradation of bisphenol A and dye by graphene-oxide $/ \mathrm{Ag}_{3} \mathrm{PO}_{4}$ composite under visible light irradiation. Ceramics International, 40, 8061-8070 (2014). DOI:10.1016/j.ceramint.2013.12.159

[8] X. Wang, H. Tian, Y. Yang, H. Wang, S. Wang, W. Zheng, Y. Liu, Reduced graphene oxide/CdS for efficiently photocatalystic degradation of methylene blue. Journal of Alloys and Compounds, 524, 5-12 (2012). DOI:10.1016/j.jallcom.2012.02.058

[9] K. Chakraborty, S. Ibrahim, P. Das, S. Ghosh, T. Pal, Reduced graphene oxide-CdS nanocomposite with enhanced photocatalytic 4-nitrophenol degradation. AIP Conference Proceedings, 1832, (2017). DOI: doi.org/10.1063/1.4980310.

[10] F. S. Omar, H. Nay Ming, S. M. Hafiz, L. H. Ngee, Microwave synthesis of zinc oxide/reduced graphene oxide hybrid for adsorption-photocatalysis application, International Journal of Photoenergy, 2014, 1-8 (2014). DOI:10.1155/2014/176835

[11] J. Shen, W. Huang, N. Li, M. Ye, Highly efficient degradation of dyes by reduced graphene oxide-ZnCdS supramolecular photocatalyst under visible light, Ceramics International, 41, 761-767 (2015). DOI:10.1016/j.ceramint.2014.08.135 
[12] W. M. Yan, J. Huang, Z. Tong, W. Li, J. Chen, Reduced graphene oxide-cuprous oxide composite via facial deposition for photocatalytic dye-degradation. Journal of Alloys and Compounds, 568, 26-35 (2013).

DOI:10.1016/j.jallcom.2013.03.019

[13] A. Molla, M. Sahu, S. Hussain, Synthesis of tunable band gap semiconductor nickel sulphide nanoparticles: Rapid and round the clock degradation of organic dyes, Scientific Reports, 6 (2016). DOI:10.1038/srep26034.

[14] H. R. Pouretedal, F. Momenzadeh, Synthesis, characterization and study of photocatalytic activity of nanocomposites of oxides and sulfides of $\mathrm{Ni}(\mathrm{II})$ and $\mathrm{Ni}(\mathrm{III})$, Bulgarian Chemical Communications, 47, 59-65 (2015).

[15] M.-C. Rosu, M. Coros, F. Pogacean, L. Magerusan, C. Socaci, A. Turza, S. Pruneanu, Azo dyes degradation using $\mathrm{TiO}_{2}-\mathrm{Pt} /$ graphene oxide and $\mathrm{TiO}_{2}-\mathrm{Pt} /$ reduced graphene oxide photocatalysts under UV and natural sunlight irradiation. Solid State Sciences, 70, 13-20 (2017). DOI:10.1016/j.solidstatesciences.2017.05.

[16] F. Fan, X. Wang, Y. Ma, K. Fu, Y. Yang, Enhanced photocatalytic degradation of dye wastewater using $\mathrm{ZnO} /$ reduced graphene oxide hybrids. Fullerenes, Nanotubes and Carbon Nanostructures, 23, 917-921 (2015). DOI:10.1080/1536383x.2015.1013187

[17] A. Ucar, M. Findik, I. H. Gubbuk, N. Kocak, H. Bingol, Catalytic degradation of organic dye using reduced graphene oxide-polyoxometalate nanocomposite. Materials Chemistry and Physics, 196, 21-28 (2017). DOI:10.1016/j.matchemphys.2017.04.047
[18] N. Mittal, A. Shah, B. Parasher, P. B. Punjabi, V. K. Sharma, Photocatalytic degradation of Azure B in aqueous solution using manganese dioxide as photocatalyst, Int. J. Chem. Sci., 8, 451-458 (2010).

[19] R. Ameta, P. Jhalora, Photocatalytic degradation of Azure B in aqueous solution by calcium oxide, J. Current Chem. Pharma. Sci., 4, 22-29 (2014).

[20] R. Upadhyay, O. P. Sharma, S. Jakar, R. K. Sharma, M. K. Sharma., Photocatalytic degradation of azure B using copper hexacyanoferrate(II) as semiconductor, Int. J. Chem. Sci., 10, 956-966 (2012).

[21] T. Aarthi, P. Narahari, G. Madras, Photocatalytic degradation of Azure and Sudan dyes using nano $\mathrm{TiO}_{2}$. J. Hazard. Mater., 149(3), 725-734 (2007).

[22] H. K. Jeong, Y. P. Lee, R. J. W. E. Lahaye, M. H. Park, K. H. An, I. J. Kim, C. W. Yang, C. Y. Park, R. S. Ruoff, Y. H. Lee, Evidence of graphitic AB stacking order of graphite oxides, J. Am. Chem. Soc., 130(4), 13621366 (2008).

[23] C. Nethravathi, T. Nishaa, N. Ravishankar, C. Shivakumarac, M. Rajamathi, Graphene-nanocrystalline metal sulphide composites produced by a one-pot reaction starting from graphite oxide, Carbon, 47(8), 2054-2059 (2009).

[24] S. G. Pan, Preparation and characterization of CuSgraphene composite, 2nd Annual International Conference on Advanced Material Engineering (AME 2016), DOI: doi:org/10.2991/ame-16.2016.15 